\title{
Where Have All the Stories and Voices Gone in Local Newspapers? The Effect Falling Advertising Revenues and the Rise of the Web Have Had on English Regional Newspapers
}

\begin{abstract}
By Richard Bowyer*
The regional newspaper industry in the UK is in freefall with sales down more than 60 percent in 10 years. With this decline has come cost-cutting. This study looks at how these cuts have manifested themselves in terms of the number of news stories now being printed in newspapers and the number of local people being quoted in the newspapers. The study has looked at a number of regional newspapers across 30 years to show the effect of the changing face of the newspaper business as the audience and advertising have moved online. The research includes interviews with experts on whether story count mattered and if fewer stories and local voices have damaged the product. This paper finds that generally newspaper companies with a web-first culture have been forced to reduce their local news content in their printed products as they concentrate their resources online. While fewer stories and voices cannot be blamed for the complete demise of the newspapers, it is a consequence of cost-cutting and disadvantages the product. Opinions do vary on the needs for high story count, but this paper shows that most experts believe it is important and that without it, printed newspapers have been damaged.
\end{abstract}

Keywords: newspapers, regional, decline, stories, quotes

\section{Introduction}

Newspapers used to pride themselves in having dozens of local stories in the newspaper. During the 80s, 90s and 00s, there was a "value for money" mantra, with some editors keen to give readers as many stories as possible. There are few academic texts which refer to story count, but of those found the view is that fewer stories as being a bad thing without any real supporting evidence. Franklin and Murphy (1998, p. 15) suggest that editors realised they were battling to get readers to buy newspapers for the cover price so packed the newspaper full of "soundbites or word bites, we are catering for a public which has a grasshopper mentality" it goes onto say "you go for a big read and keep the story count as high as possible to keep the audience's attention". Also, in a critique of free newspapers, it is inferred that the newspapers have a low story count, effectively, an implied criticism of the product (Franklin and Murphy, 1998, p. 138).

With fewer stories in a newspaper, the number of people quoted will inevitably fall. As a rule of thumb, some, but not all newspaper editors tended to look for a

\footnotetext{
"Senior Lecturer, University of Derby, UK.
} 
minimum of three quotes per story to create balance. The "three quote" rule derives from the Watergate scandal in which journalists Woodward and Bernstein had an "unwritten rule" that they would not publish unless there was two additional sources confirmed to support the original source, it became known as the "three source rule" (Harcup, 2015, p. 86). The key reason for fewer stories in newspapers falls at the feet of a shift in emphasis from print to online. According to Jenkins and Kleis Nielsen (2018), advertising was the most important source of revenue for many local newspapers and because they were the main or only publication in most communities, they were powerful and operated as profitable businesses. This business model has changed with advertisers investing in the web, which is dominated by large US-based platform companies that offer low prices, precise targeting, and unduplicated reach such as Facebook and Google. This has led to the trade body for newspapers in the UK, News Association, to ask for greater transparency about advertising revenues obtained by these firms on the back of existing news organisations (Jenkins and Kleis Nielsen, 2018). Furthermore, in the wake of criticism over the damage caused to local and national journalism by these companies, they have both created schemes to help pay for journalism in the UK (Nilsson, 2019; Waterson, 2018). However, local newspapers still cannot compete directly, and online, their traditional business model, advertising, is challenged. According to the Cairncross Review (Cairncross, 2019) more than 300 local newspapers have closed and the number of frontline print journalists has dropped by 6,000 in the past decade from 23,000 to 17,000 . The report also revealed print advertising revenues have dropped by more than half over the last 10 years, from nearly $£ 7$ billion to just over $£ 3$ billion. According to (Hill, 2016) providing news and comment, which had always been the preserve of the print media was unshackled by the internet, which led to sales of newspapers reducing drastically, which in turn hit advertising revenues, leading to a reduction in income. Due to the fact that newspapers relied so heavily on advertising, on average 80 per cent for regional newspapers, the movement of this advertising income away from newspapers to online meant that printed media was left in a dire financial position (Hill, 2016). According to (Hill, 2016), the only way around the dilemma was to raise the cover price of the newspaper to make up for the shortfall in income. However, this could not be done quick enough to fill the income gap, so newspapers were left with only one option, cost-cutting. The situation is similar in the United States where the loss of journalism jobs and 20 per cent of newspaper closures are blamed on the stranglehold Facebook and Google have on online advertising income (Lipman, 2019).

Jenkins and Kleis Nielsen (2018) state that the need for local news organisations, particularly newspapers, to adapt to these trends and demonstrate their relevance while facing declining advertising revenues, circulation rates, and staff sizes has resulted in a perfect storm for layoffs, buyouts, and even closures. A further consequence of this is the move to online first, as demonstrated by Trinity Mirror, now Reach Plc, (Reid, 2014). In this document the move to digital-first was described by the then editorial director of Trinity Mirror, Neil Benson, as crossing the "Rubicon". What this effectively meant was that content was prepared first for online before being put into the newspaper. It also highlights a shift in 
emphasis in terms of staffing numbers with a smaller print unit created sitting next to a larger online department. The result of this online first policy is that putting together a paper in less time with fewer people has led to a reduction in stories and the time to quote a larger number of people. Some local pages have also been lost in daily newspapers to centralised content pages being used to provide content in the paper. According to Sharman (2017) Trinity Mirror made 40 staff redundant in a plan to use more shared content which included the creation of ready-made pages with generic content. As an aside, while regional newspapers have had to reduce story count to cope with the demands of online this void has to a certain extent been filled by hyper-local websites (Harte, 2017). Another reason for the reduction in stories is that production and subbing staff have been at the heart of job cuts in newspapers with the need for content creators, but not content refiners. According to Nel (2010) in a report on job losses in the newspaper industry almost a quarter of those who lost their jobs were sub-editors, the biggest group. The other part of this research looked at the number of quotes in stories. Quotes are important to the story and bring it to life (Pape and Featherstone, 2005, p. 38). They add that the quotes bring a news story to life and "add human interest and authenticity", "quotations are the life force of a news story. They bring direct human impact into what otherwise runs the risk of becoming a dry series of factual statements". (Reeves, 2015, p. 121)

According to Spark and Harris (1997, p. 66) quotes add to the accuracy of a story and provide the reader with original information to "form their views". Also, direct and indirect quotes make it clear to the reader the source of the information. In an updated version, Spark and Harris (2016, p. 55) add that no report with more than 100 words is complete without a quote. Furthermore, words from an eyewitness tell a story in a "fresher, simpler" and more "moving" than a journalist telling the story themselves. Telling a story is all about balance and as mentioned earlier accuracy which can come from quotes. Accuracy according to Harcup (2015, p. 76) is described as the single most important part of journalism and adds that little else really matters. Of course, this is often easier said than done and there is a warning from Spark and Harris (2016, p. 194) that in the cost-cutting environment of newspapers, the expectation that journalists should write more content which is less likely to be checked making accuracy harder to ensure. Also, it is vital to remember the Editors' Code of conduct (IPSO, 2018) which journalists adhere to and refers to accuracy and the need for the press not to publish inaccurate information. The reason accuracy has been raised here is that while eyewitnesses can provide different information, the correlation between the stories helps to build the picture of the story.

\section{Methodology}

Five newspapers were chosen for this initial study (see Table 1). They are from four different regional daily newspaper groups from various parts of the country. The papers chosen were the Derby Telegraph, the Express and Star, Wolverhampton, Sheffield Star, Norwich News and Newcastle Chronicle. The 
Derby Telegraph and the Newcastle Chronicle are from the biggest regional newspaper group in the UK, Reach Plc (Reach Plc, 2019). The idea of choosing two newspapers from one group was to add an internal comparison for the research, to note whether the same reduction in stories and people quoted was a company-wide policy. The cities the newspapers serve have similar populations with the exception of Sheffield, which is larger; Derby (pop: 262,971); Wolverhampton (pop: 240,937); Sheffield (pop: 541,763); Norwich (pop: 195, 971); Newcastle-upon-Tyne (pop: 282,708), (Office for National Statistics, 2016).

Table 1. Figures from the Audit Bureau of Circulation (ABC, 2019) and which also Appeared in the Trade Publication UK Press Gazette (Mayhew, 2017a)

\begin{tabular}{|l|c|c|c|}
\hline $\begin{array}{l}\text { Newspaper } \\
\text { name }\end{array}$ & Newspaper owner & $\begin{array}{c}\text { Newspaper sales } \\
\text { December 2018 }\end{array}$ & $\begin{array}{c}\text { Average daily } \\
\text { online unique } \\
\text { users } \\
\text { June 2017 }\end{array}$ \\
\hline Derby Telegraph & Reach Plc & 15,029 & 92,858 \\
\hline Express and Star & $\begin{array}{c}\text { Midland News } \\
\text { Association }\end{array}$ & 38,690 & $98,733^{*}$ \\
\hline Sheffield Star & $\begin{array}{c}\text { JPI Media (now National } \\
\text { World) }\end{array}$ & 12,609 & 101,055 \\
\hline Norwich News & Archant & 25,631 & 19,235 \\
\hline $\begin{array}{l}\text { Newcastle } \\
\text { Chronicle }\end{array}$ & Reach Plc & 19,259 & 297,527 \\
\hline
\end{tabular}

Note: Midland News Association, owners of the Express \&Star, is not independently audited for web audience figures; however, MNA figures put average daily unique users for April 2017 at 98,733 on expressandstar.com.

The newspapers chosen to review during this period were for the years 1998 , 2008 and 2018. It was decided that three days' worth of each newspaper would be looked at in May covering all of those years. The newspapers viewed were the final editions of each newspaper. Copies looked at were Monday, Wednesday and Friday. To get an idea of the volume of stories and for accuracy, stories not counted were in any features, supplements, any national news (unless localised), any national sports stories, advertising features, letters. Effectively, the stories had to original local news stories/news features. Pape and Featherstone (2005) describe local news as only being news if it happens in the right place or area. This is reinforced by Spark and Harris $(2010$, p. 2) who say that editors create a framework for a publications' new judgements so a "local newspaper will concentrate on local people". The stories described here were the ones that were counted for this paper. Not only were the stories counted, but also the number of local voices in the stories. National representatives of big organisations were not counted, but a local person speaking for a national organisation was counted. Also, the number of pages carrying local news stories has been counted to reflect if there is any change in paginations.

The research methods employed were both qualitative and quantitative. According to Dawson (2002) qualitative research explores "attitudes, behaviour and experiences through different methods including interviews". In this research 
there are a number of interviews with industry experts talking about story count and quotes. According to Tracy (2019) a phrase which is used to class this sort of research is grounded theory. This means that rather than tackling the data with "pre-existing theories" the researcher collects data and analyses it line-by-line creating themes from the data rather than adding ready-made themes to the outcomes (Tracy, 2019, p. 30). Also, this paper involves quantitative, because a number of newspapers were examined generating statistics (Dawson, 2002). To support this Neuman (2007) describes the research data as quantitative, an expression in numbers or qualitative, an expression in words, visual images, sounds, or objects. The quantitative research method used was stratified sampling because a controlled sample of newspapers was selected. According to Neuman (2007) this form of research guarantees representativeness or fixes the proportion of different strata within a sample. In general, stratified sampling produces samples that are more representative than simple random sampling if the stratum information is accurate.

The second part of this research was focused on talking to industry experts about the value of story count to a newspaper. For example, my findings show that some newspapers had a low story count in 1998 and there was a general feeling among some newspaper editors that story count was not the golden nugget to achievement. I spoke to four experts who have been involved in the newspaper industry. Three of them did not have a direct connection to the research. They were Peter Sands, a former editor and then editorial trainer for Sands Media Services and well-known commentator on the industry and a journalist for more than 40 years; Mike Sassi, former editor of the Notts Post, and a journalist for more than 30 years; Mark Charlton, former night editor Leicester Mercury, who was a journalist for more than 15 years and is now Head of Public Engagement at de Montford University. The fourth expert I spoke to was Martin Wright, Editorin-chief Midland News Association. His newspaper was part of the research and the reason I asked him to be involved was so we could discuss the results because his newspaper tended to buck the trend in terms of reduced story count and local voices. In Appendix A are the questions asked to the experts.

\section{Background}

The recent Cairncross Review, commissioned by the UK Government and headed by Dame Frances Cairncross, into a sustainable future for high-quality journalism highlighted the issues facing both the regional and national press. Figures from the report show that print sales of national and local printed newspapers have fallen by roughly half between 2007-2008 and 2017-2018 (Mayhew, 2019a). The report highlighted that the sales of national newspaper print editions had fallen from $11.5 \mathrm{~m}$ daily copies in 2008 to $5.8 \mathrm{~m}$ in 2018 and regional newspapers from $63.4 \mathrm{~m}$ weekly copies in 2007 to $31.4 \mathrm{~m}$ in 2017 (Cairncross, 2019). Other key figures show that print advertising revenues have fallen by 69 per cent in a decade and the number of frontline journalists in the industry fell from about 23,000 in 2007 to 17,000 in 2019. The consequences are highlighted by 
Waterson (2020) who describes that during the last decade newspaper groups have merged, staff laid off and offices closed in a final effort to cut costs. He adds that the result of these cuts is often a "single junior regional reporter left trying to fill a town's newspaper".

\section{Story Count: Derby Telegraph and Newcastle Chronicle}

Graph 1. The Derby Telegraph 1998-2018 Showing the Number of Local News Stories, Local Pages and Local People

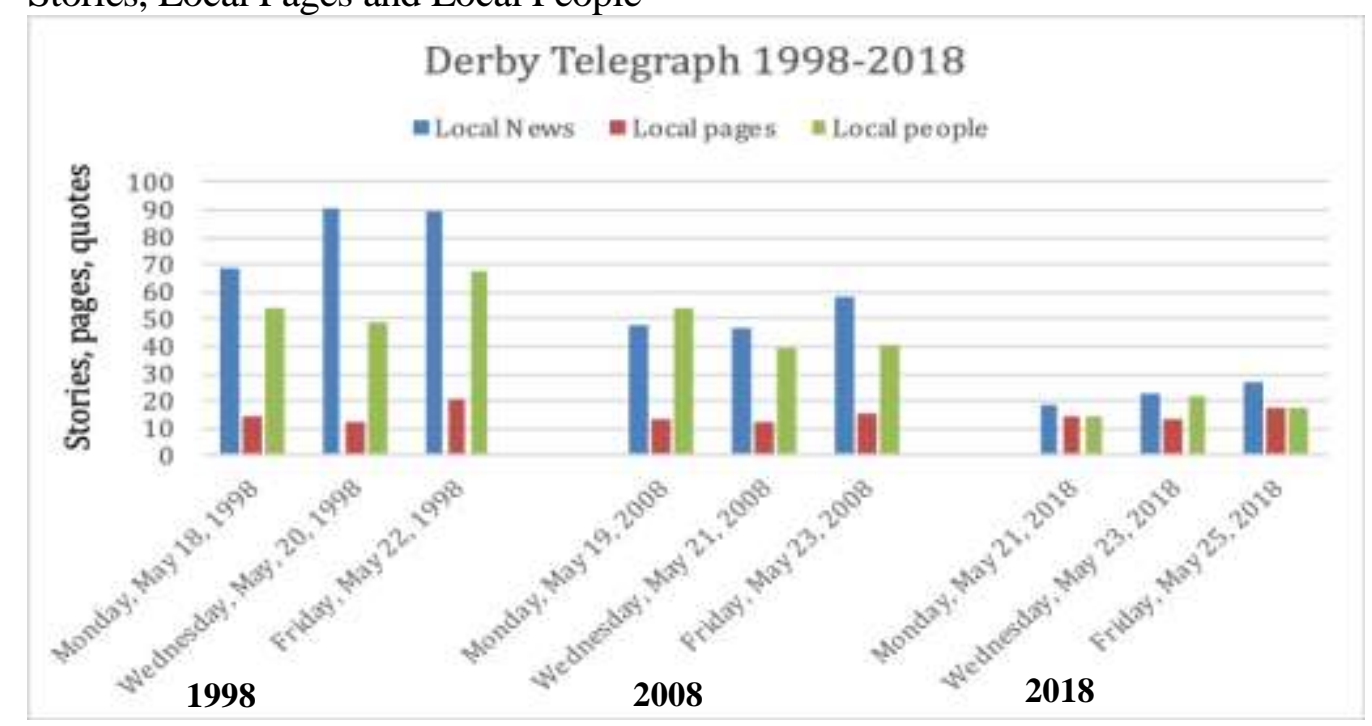

Graph 2. The Newcastle Chronicle 1998-2018 Showing the Number of Local News Stories, Local Pages and Local People

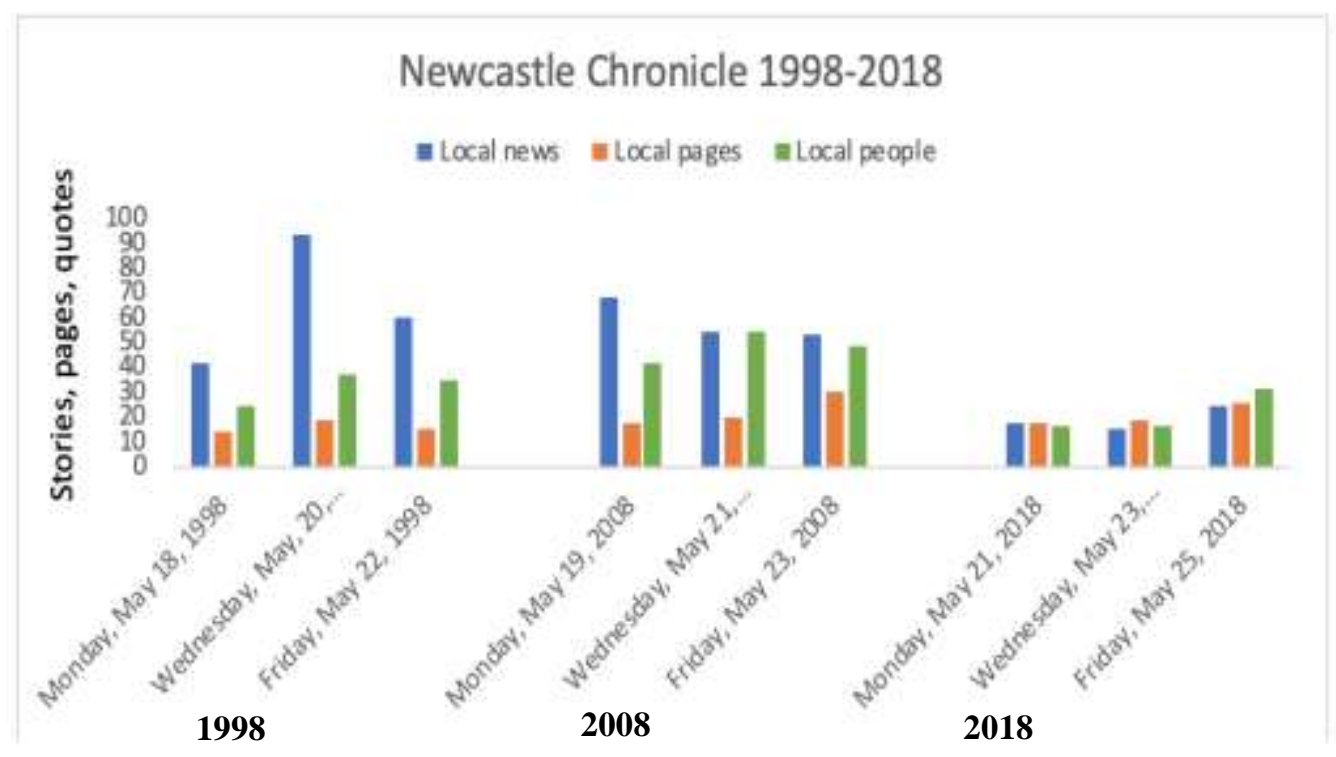

Both of these newspapers belong to the Reach Plc group, formerly Trinity Mirror. During the 1990s Derby was owned by Northcliffe Newspapers before 
being later sold to Local World then Trinity Mirror Sweney (2016), which later became Reach Plc (BBC News, 2018). The Chronicle was owned by Thomson before being sold to TM in 1995 (Lambourne, 2014). In 1998, with different owners, there was a similar philosophy. The Telegraph is packed with stories (see Graph 1), up to 90 a day and there are also a lot of local people quoted, just under 68 on one day when there were 21 local news pages. The Chronicle (see Graph 2) also had a high number of stories, 94 one day, but the number of local voices was lower, 38 being the highest. With the high number of stories in the Telegraph in 1998 , there is a decline in 2008 , with the highest number of stories in the three days at 58 compared with the lowest in 1998 which was 69 . There is still a decent number of local voices in the newspaper with a high of 54, which is bigger than the lowest number in 1998 which is 49. In line with other newspapers in this sample group, the Chronicle in 2008 still had a high story count, a maximum of 69 in one edition, and its local voices on all three days was higher than 1998, with 42, 55 and 49 people quoted compared with 25,38 and 35 in 1998. However, the major difference can be seen in 2018 for both newspapers. The Telegraph local story count has dropped to between 19 and 27 and the local voices between 15 and 22. This is a dramatic change from the height of 1998 with 90 stories and 60 people quoted. Similarly, the Chronicle figures for 2018 show that the number of local stories has dropped to between 16 and 25 from 42 to 94 in 1998 and 54 to 69 in 2008. The number of local voices has also fallen from highs of between 42 to 55 in 2008 to 17 to 32 in 2018.

\section{Sheffield Star}

Graph 3. The Sheffield Star 1998-2018 Showing the Number of Local News Stories, Local Pages and Local People

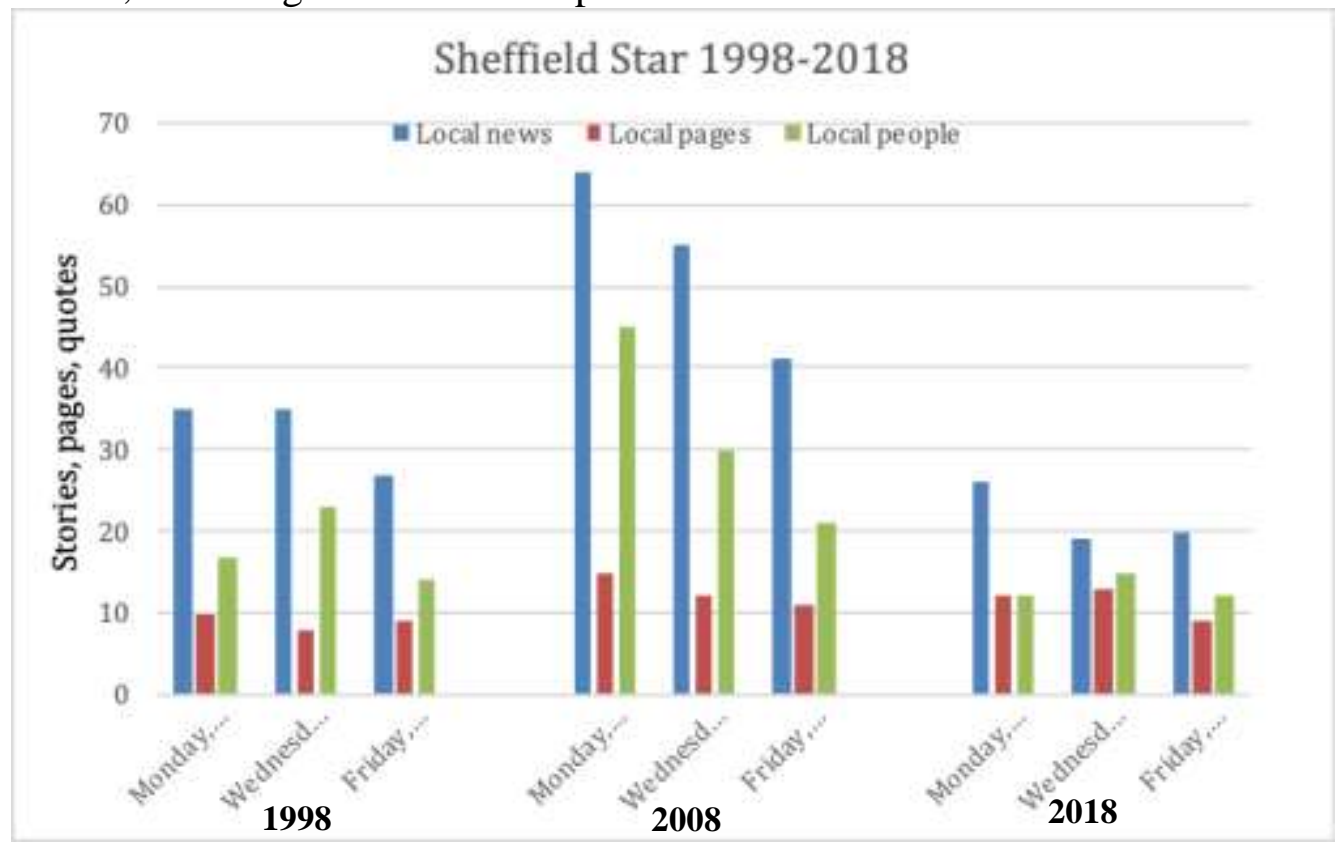


The newspaper is owned by the newly-created JPIMedia, which bought the newspapers from Johnston Press after agreeing to wipe out $£ 135 \mathrm{~m}$ of the company's debts in return for control of the business (Linford, 2018). JPI was recently sold in December 2020 to National World, which is run by David Montgomery who was behind Local World, which was bought by Reach Plc (Ponsford, 2020). In 1998 (see Graph 3) the number of pages set aside for local news was comparatively low, between eight and 10 and this reflects on the number of stories which peaked at 35 and went down to 27 . The number of local voices was between 14 and 23. In 2008 the newspaper had more local news pages and the number of stories rose to 64, 55 and 41 and local people quoted 45, 30 and 21, compared with 17, 23 and 14 in 1998. Once again 10 years later there is a decline in 2018 from 2008. In 2018 the number of local stories was 26, 19, 20 and voices 12, 15, 12, a large drop from 2008 and a smaller drop from 1998. This differential between 1998 and 2018 is explored further in the discussion on the Norwich News.

\section{Norwich News}

Graph 4. Norwich News 1998-2018 Showing the Number of Local News Stories, Local Pages and Local People

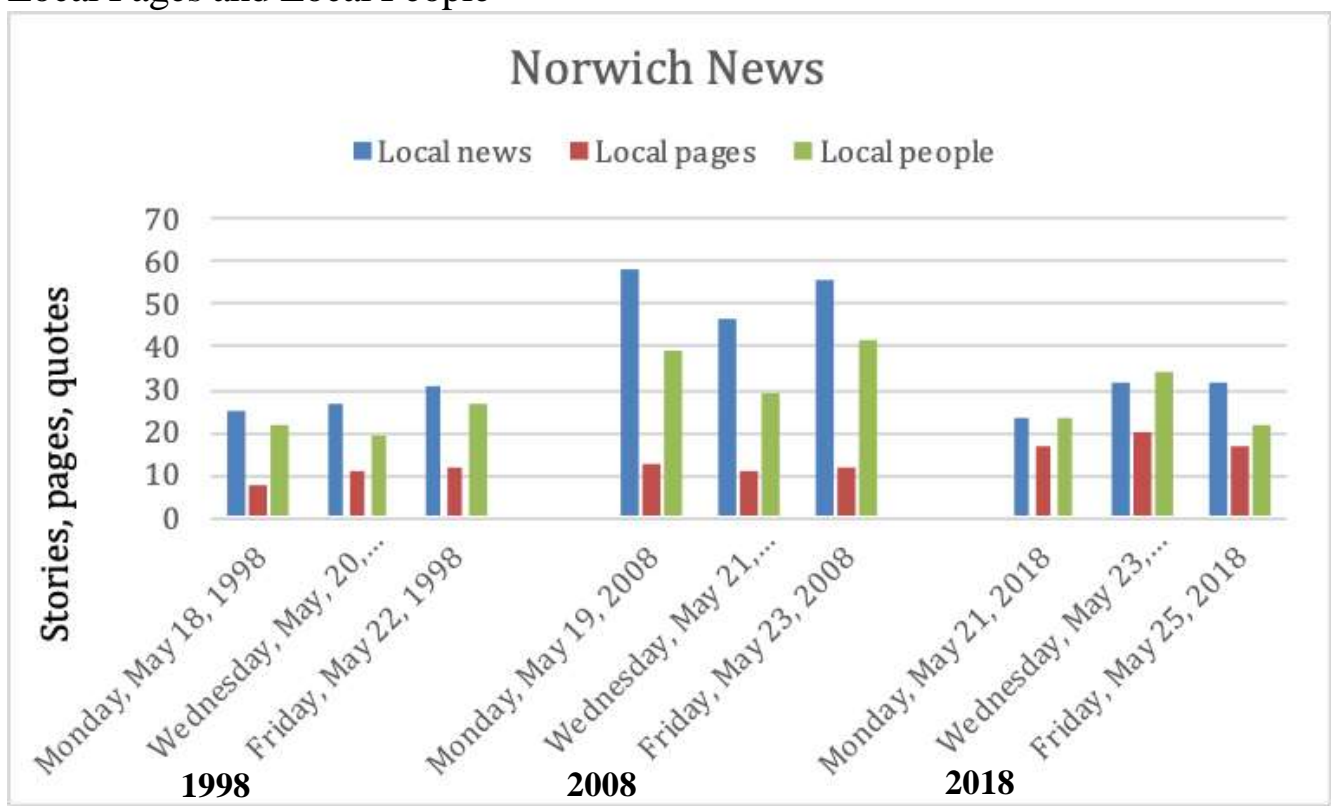

The newspaper is owned by Archant Group. It was part of the Eastern Counties Newspapers Group but the company changed its name to Archant to have broader appeal around the country in 2002 (Archant, 2019). This paper follows a similar pattern to the Sheffield Star with an increase in content in 2008, but either side of this date there are fewer stories and voices. In terms of story count and local voices, the greatest parallel between eras is 1998 and 2018. In 1998 there were 25, 27, 31 new stories compared with the 2018 figures of 23, 32, 32. The number of local voices in 1998 was 22, 19, 27, compared with 23, 34, 22. Once again this makes the steepest decline in content from 2008 to 2018. In 2008 there were 58, 47, 56 news stories and 39, 29, 42 local voices. The question to be 
asked was why the Norwich and Sheffield newspapers had a lower story count in 1998 ? In 2018 the issue around fewer stories and voices is concerned around the reduction in staff and emphasis for web first, in 1998 there was a movement in some areas of the regional press to lead by design and not story count. This is supported by Paul (2020), a freelance editorial designer and lecturer, who helped to re-design the Norwich News in 2004. He suggests that the reason for fewer stories in the News in the late 1990s was possibly due to the desire to change the feel of newspapers, with an emphasis of bigger headlines and photographs as they changed with the times and technology. It was also believed that that lifestyle and leisure content should be more prominent which probably meant the emphasis was less on news and more on feature/life-style content. So the newspaper did have a lot of content, but it was not necessary the type of content considered by this research. Paul (2020) added that with the introduction of colour, newspapers were becoming brighter and breezier, with less emphasis on high story content. Frost (2012) supports this idea by suggesting that story counts are a consideration when designing pages. For example, if the design calls for bigger headlines and photographs, the pages will reflect this by having fewer stories. Berry (2004) states that newspapers redesign frequently to sharpen their identities with readers and out of necessity to meet economic pressures and changes in technology. This means that changing the look is often due to new approaches to production and also the economic pressures applied from competition, either other print products or the web and TV (Berry, 2004). Also how a newspaper looks depends on how the senior editorial team perceive the readership whether that is big sans serif capital letters for headlines, thick rules to restrained headline sizes and background panel boxes (Berry, 2004).

\section{Wolverhampton Express \&Star}

Graph 5. Express \& Star 1998-2018 Showing the Number of Local News Stories, Local Pages and Local People

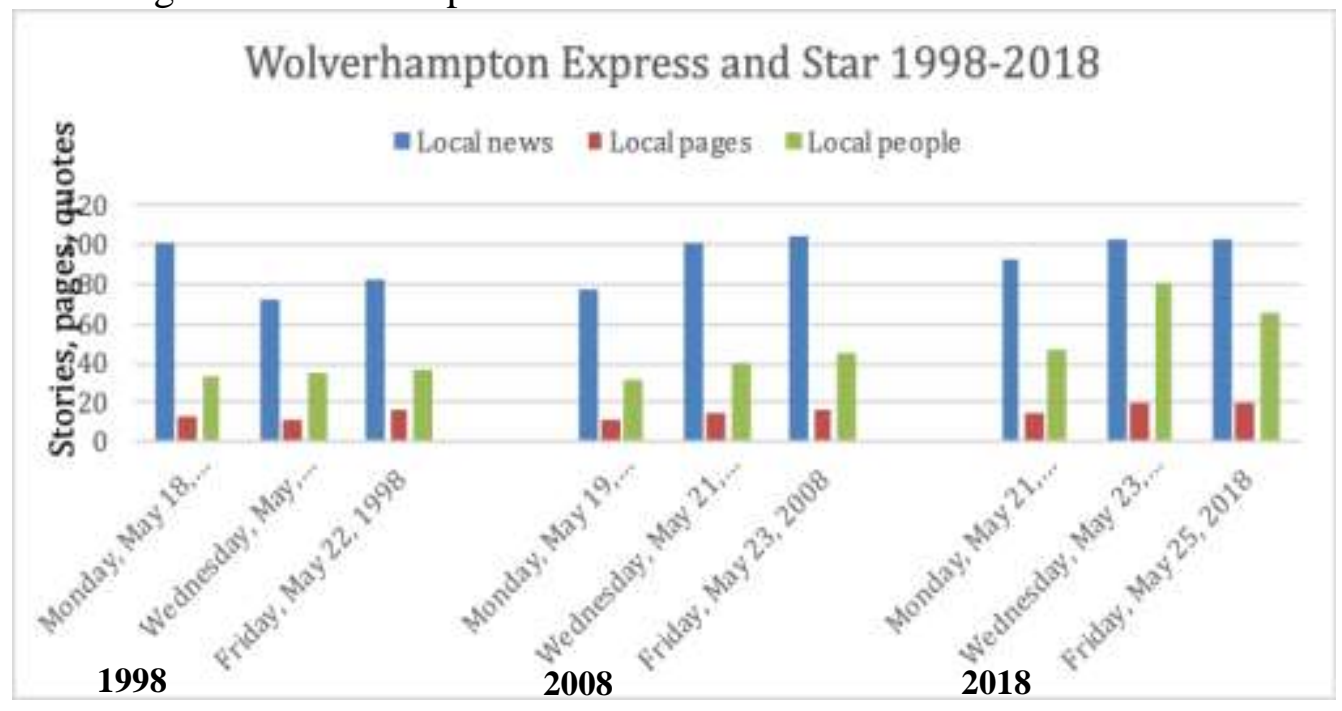


The newspaper is owned by Midland News Association. The paper was founded in the city in the 1880 s by the Scottish-American millionaire Andrew Carnegie and a group of radical Liberal Party members, including Thomas Graham. The Express \& Star has steadily overtaken its rivals to become the biggest-selling regional evening newspaper in Britain outside London (Archant, 2019). This newspaper bucks the trends because today there are more local stories and more local people quoted than in the previous years (see Graph 5). The newspaper policy of having a high number of national and international stories throughout the paper has changed to a concentration of local news. Its local story count has been incredibly consistent 1998: 101, 72, 83; 2008: 77, 101, 107; 2018: 93, 102, 103. The number of local voices has also gone up which reflects the decline in national and international stories in the newspaper. For example, the number of national news stories in the Monday edition of the newspaper was 64 in 1998 which dropped to 52 in 2008 and 19 in 2018. This move to fewer national stories and a greater emphasis on local stories is reflected in the move of the newspapers to overnight production. At the time, the then editor Keith Harrison admitted there would be fewer national stories as the organisation shed 76 staff as part of this process (Linford, 2014). However, what we can see is a concentration on the production of local news stories which is reflected in the consistently high local story count.

\section{Qualitative Research Questions and Answers (See Appendix A for Questions)}

According to Sassi (2019) ${ }^{1}$ during his time as a trainee reporter in the 1980 s the biggest complaint he received was that there was "nothing in the paper". $\mathrm{He}$ firmly believed that readers needed to get value for money and this came from story count. He added that while some editors obsessed with having as many pages as possible, he was more concerned with packing the newspaper full of stories. Sassi $(2019)^{2}$ said he simply wanted every edition of his paper to carry at least 100 local (no national) news excluding sports, features and business stories. The theory was that local people wanted to read about their friends and neighbours - the streets where they live, the places that they shop and the schools where their children are pupils, he said. Sassi (2019) ${ }^{3}$ added that he did not think this formula was detrimental to the newspapers because he felt the more stories you gave readers thee more they would want to read on. According to Sands $(2018)^{4}$ the mantra of the 1980s-1990s was high story count. He said that it came out of the desire to provide readers value as paginations decreased. However, he felt that the content used to fill the papers was of such poor quality that it would drive readers away. Charlton (2019) ${ }^{5}$ agreed that there an emphasis on story count in the past, although he did not believe it was detrimental to the newspaper. He added that the theory was that the more stories, the more chance there was of a reader finding

\footnotetext{
${ }^{1}$ Mike Sassi Interview 2019.

${ }^{2}$ Mike Sassi Interview 2019.

${ }^{3}$ Mike Sassi Interview 2019.

${ }^{4}$ Peter Sands Interview 2018.

${ }^{5}$ Mark Charlton Interview 2019.
} 
more items of interest. The belief in high story count is supported in what was asked for at the Leicester Mercury at one time which was a maximum of eight paragraphs per story unless it was exceptional. This ensured that the number of stories on a page was high. Wright $(2019)^{6}$ said that it is in the culture of the Express and Star to maintain high story count. He added that if a newspaper only had 20 to 30 local stories in and few local voices in, it was difficult to sell.

According to Wright $(2019)^{7}$ and Sassi $(2019)^{8}$, story count was the key to selling newspapers and that it mattered that the number of stories and voices were high. Sassi $(2019)^{9}$ said that "in simple terms, the more stories you give readers, the more chance you have of persuading them to read on". This was echoed by Wright who said without story count the newspaper was hard to sell. Charlton (2019) ${ }^{10}$ was of the opinion that five really well-written interesting pieces is better than 10 not-so well-written and not-so interesting stories. However, he added that what one person finds interesting, another does not. The number of stories does matter, although within the parameters on a well-designed and constructed page that is easy on the eye (Charlton, 2019) ${ }^{11}$. However, quality over quantity was the bedrock of a newspaper, according to Sands (2018) ${ }^{12}$. According to Sands (2018) ${ }^{13}$ it was all too easy to fill the columns with press releases, fillers and council minutes. Often there were columns of local stories most of which were irrelevant to the readership. If there was a story about choir practice, did anyone care, so the only people it did interest were members of the choir and they did not because they already knew when practice was on (Sands, 2018) ${ }^{14}$. Sands (2018) ${ }^{15}$ added that newspapers "deluded" themselves into thinking that putting a strong headline on a diary event offered value for money so the desire for high story count could turn readers away.

There are many reasons for the rapid decline in newspapers and their readership but one of the biggest must be that most daily papers now carry less than one third of the truly local news stories that would have once (Sassi, 2019) ${ }^{16}$. $\mathrm{He}$ added that too many readers think there's nothing in their local paper. According to Charlton (2019) ${ }^{17}$ there is no doubt that there are fewer local stories in the newspapers but this was down to logistics rather than a principle. He added that newspapers have much fewer staff today than they did 10 years ago, an estimated 6,500 regional jobs have been lost since 2005 (Hutton, 2018). The Leicester Mercury's editorial department was just over 100 in 2008 before the various rounds of redundancies (Charlton, 2019) ${ }^{18}$, it is now 40 or even slightly

\footnotetext{
${ }^{6}$ Martin Wright Interview 2019.

${ }^{7}$ Martin Wright Interview 2019.

${ }^{8}$ Mike Sassi Interview 2019.

${ }^{9}$ Mike Sassi Interview 2019.

${ }^{10}$ Mark Charlton Interview 2019.

${ }^{11}$ Mark Charlton Interview 2019.

${ }^{12}$ Peter Sands Interview 2018.

${ }^{13}$ Peter Sands Interview 2018.

${ }^{14}$ Peter Sands Interview 2018.

${ }^{15}$ Peter Sands Interview 2018.

${ }^{16}$ Mike Sassi Interview 2019.

${ }^{17}$ Mark Charlton Interview 2019.

${ }^{18}$ Mark Charlton Interview 2019.
} 
less. It is quite clear that this reduction cannot sustain the same level of story count as in the past. Also, the move towards digital newsrooms now means that, in nearly every centre, the newspaper is literally an "after thought". The Express \& Star is one paper which has bucked the trend and has changed its philosophy of the 1990s and early 2000s to produce more local news stories in the paper. Every newspaper has had to make changes to their staffing, staffing numbers are down from the 1990s, according to (Wright, 2019) ${ }^{19}$. To fulfil the mantra of the newspaper to maintain story count, the company has attempted to be more efficient on the production side to maintain levels of reporting.

"The introduction of template pages has allowed us to scale back on the production which allows the level of reporting to be the best we can do. We believe value for money involves a large range of stories. If someone is paying $75 p$ during the week and $90 \mathrm{p}$ at the weekend we believe we have to maintain story levels to offer value for money" (Wright, 2019) ${ }^{20}$.

According to (Wright, 2019) ${ }^{21}$ there were fewer local stories in the early periods of this research paper because readers used to rely on the Express \&Star to provide national news stories. However, with news around the world available within seconds, the paper had made a concerted bid to provide more local, exclusive stories than have national and international stories on its pages.

Reporters now mainly write for the website and their stories are re-packaged (cut and pasted) for the newspaper (Charlton, 2019) ${ }^{22}$. This he said further impacts on the number of stories as reporters are asked to concentrate on stories with "the numbers" and often need to sort out live updates, video, pictures, Facebook Live and even, on occasions, audio for some of those stories. All of this impacts on the number of stories that can be physically produced. The move towards online means that some content is "not suitable" for the newspaper as reporters may be producing generic content, which could even be re-written national stories, simply to capitalise on trending stories. Reach Plc newspapers in Leicester, Nottingham and Derby have a team (The Trending Unit) doing this on a daily basis for the three websites of the cities. This again takes more staff away from the business of writing stories (Charlton, 2019) ${ }^{23}$. He added that the reduction in story count is by necessity, not invention. For example, when he worked in Leicester, a senior subeditor fills the back of the newspaper without any newsdesk or reporter involvement from press releases and information contributed by email. There are fewer local stories in regional newspapers and this was due to diminishing resources and the focus of the resources which are left to the publishing online first $\left(\right.$ Sassi, 2019) ${ }^{24}$. He said that the biggest battle was between quality and quantity and that with fewer staff errors and mistakes crept in with the quantity required. Add this to the demands of the needs for more commercial journalism and to feed

\footnotetext{
${ }^{19}$ Martin Wright Interview 2019.

${ }^{20}$ Martin Wright Interview 2019.

${ }^{21}$ Martin Wright Interview 2019.

${ }^{22}$ Mark Charlton Interview 2019.

${ }^{23}$ Mark Charlton Interview 2019.

${ }^{24}$ Mike Sassi Interview 2019.
} 
the website something had to give and the victim was story count and the concentration of efforts on the newspaper. Many newspapers decrease the number of stories they have put into their newspapers, but the Express \&Star stands out for going the other way, ensuring story count is high and full of local news. The company believed in maintaining story count to offer value for money with the newspaper costing 75p in the week and 90p at the weekend (Wright, 2019) ${ }^{25}$.

All of the experts firmly believed that local voices in newspapers were an essential part of the regional newspaper. According to (Charlton, 2019) ${ }^{26}$ there are fewer voices in newspapers and the problem is a time factor with reporters not having enough time to speak directly to people and relying more and more on social media to "lift" quotes, often these people unknown to the report with vague pseudonyms. He added that more readers relate to real people quoted with a name, age, occupation and an address. The more people quoted, the more chance people actually have of knowing someone in the newspaper and that brings a connection. Balance is important in news stories and this was obtained by talking to people about the subject according to Sassi $(2019)^{27}$ and this was echoed by (Wright, $2019)^{28}$ who believes that sending reporters out on stories and talking to local people was essential for the collation of balanced news reports. Names and pictures of local people were big sellers (Sands, 2018) ${ }^{29}$ and if you were in the paper, the whole street knew about it. There is certainly a danger of an increasing disconnect between communities and their paper if it is full of rent-a-quote councillors and corporate types. Perhaps real people are more likely to be found in the increasing number of hyperlocal independent titles which tend to be out and about in the community (Sands, 2018) ${ }^{30}$.

\section{Empirical Investigation into Story Count and Quotes in Regional Newspapers: Results}

What this study was attempting to achieve was to show the effect on the production of local news and time pressure to ensure local voices were in the newspaper as they moved away from print to online. With the number of newspaper closures at 245 titles since 2005 (Mayhew, 2019b) and according to Hutton (2018) regional editorial staff numbers halved to 6,500 during the same period with staff cuts, centralised newsrooms and cuts in production teams, how newspapers are produced has drastically changed. As a general rule, it is clear that the number of stories in the papers sampled and the number of voices in them has declined. This is shown in the figures for Derby Telegraph and Newcastle Chronicle which shows high story count and voices in 1998 and 2008 and a serious decline in 2018. Both Norwich and Sheffield show that stories and quotes

\footnotetext{
${ }^{25}$ Martin Wright Interview 2019.

${ }^{26}$ Mark Charlton Interview 2019.

${ }^{27}$ Mike Sassi Interview 2019.

${ }^{28}$ Martin Wright Interview 2019.

${ }^{29}$ Peter Sands Interview 2018.

${ }^{30}$ Peter Sands Interview 2018.
} 
are similar in numbers between 1998 and 2018, but show a sharp decline from 2008. What maybe key here is that in 1998 a choice may have been made to have fewer stories on design-based led pages, but the decline from 2008 to 2018 is based around changing working practices and fewer staff. The Wolverhampton Express \& Star is an anomaly with a fairly consistent story count and in 2018 a large amount of local voices as discussed earlier which was introduced as the newspaper went to overnight printing. The charts below (see Table 2) look at the sales figures and the cost of the newspapers during the period of the research to add context to the discussion.

Table 2. The Newspaper Sales and Cost of the Newspapers Used during this Research

\begin{tabular}{|c|c|c|c|}
\hline Newspaper name & Date & Sales figure & Cost of paper \\
\hline Express \&Star & December 1998 & 186,969 & $30 \mathrm{p}$ \\
\hline Norwich News & December 1998 & 36,458 & $30 \mathrm{p}$ \\
\hline Derby Telegraph & December 1998 & 60,691 & $29 \mathrm{p}$ \\
\hline Sheffield Star & December 1998 & 84,948 & $28 \mathrm{p}$ \\
\hline Newcastle Chronicle & December 1998 & 109,685 & $26 \mathrm{p}$ \\
\hline Newspaper name & Date & Sales figure & Cost of paper \\
\hline Express \&Star & December 2008 & 130,216 & $38 \mathrm{p}$ \\
\hline Norwich News & December 2008 & 21,030 & $40 \mathrm{p}$ \\
\hline Derby Telegraph & December 2008 & 35,152 & $35 \mathrm{p}$ \\
\hline Sheffield Star & December 2008 & 47,216 & $40 \mathrm{p}$ \\
\hline Newcastle Chronicle & December 2008 & 67,103 & $42 \mathrm{p}$ \\
\hline Newspaper name & Date & Sales figure & Cost of paper \\
\hline Express \&Star & June 2018 & 42,208 & $70 \mathrm{p}$ \\
\hline Norwich News & June 2018 & 6,765 & $80 \mathrm{p}$ \\
\hline Derby Telegraph & June 2018 & 16,785 & $65 \mathrm{p}$ \\
\hline Sheffield Star & June 2018 & 13,658 & $78 \mathrm{p}$ \\
\hline Newcastle Chronicle & June 2018 & 20,756 & $75 \mathrm{p}$ \\
\hline Source: Figures provided by ABC $(2019)$ & &
\end{tabular}

\section{Conclusion}

The regional newspaper business buried its head in the sand for a decade before finally realising that the internet was a direct threat to their print business and something had to be done. Newspaper editors around the country fought hard during the 90s to protect the printed product, after all, many of them received bonuses based on performance of the newspaper, so why would they embrace the web when they feared it would steal their readers? By 2007 the game was up. Advertising, the core income of the business, up to 80 per cent for many regional newspapers, moved to the web leaving the profitable businesses needing to find a solution to the loss in revenue. The issue the newspapers had was how to make up for the lost income? The obvious path was to increase cover price, but the amount the printed products could rise at anyone time could not be done quickly enough to fill the ever-increasing gap in advertising income being lost to the web. So, the only way forward was for cost-cutting. The former Northcliffe Newspaper group (Press Gazette, 2013) was one of many organisations which looked at cost-cutting 
and created its own programme of streaming lining called Aim Higher (Deans, 2006). The cost-cutting hit all aspects of the business, including many journalists, particularly in the production area, such as sub-editors and designers. As part of the cost-cutting measures, some newspaper groups adopted the policy of getting rid of production staff and in some cases centralising subbing and production operations as part of their cost-cutting measures (Press Gazette, 2014; Mayhew, 2017b; Ponsford, 2010). With the emphasis on a web first for news policy, with fewer staff and the newspaper less prominent, it has meant fewer stories being written for the printed product and subbed and fewer local people being interviewed for print. Furthermore, as discussed by (Perch, 2017) one of the costreduction methods was to close district offices of newspapers, the outcome of this policy was not only loss of reporting staff, but another pipeline for stories also disappeared for good. The reason for this type of cost-cutting was the loss of advertising revenue. As an example, according to (Perch, 2017) in 2006 British regional newspaper group Johnston Press, which was sold to National World for $£ 10.2 \mathrm{~m}$ in December 2020 (BBC News, 2020), had taken $£ 80 \mathrm{~m}$ in revenue from property advertising, but this figure had dropped in 2014 , to $£ 22.5 \mathrm{~m}$. In the same period, Rightmove, the British property website had gone from zero revenue to more than $£ 167 \mathrm{~m}$. A further issue which has arisen is that content required for online is not always transferable to newspapers, the obvious content unavailable includes audio and video, but often the style of writing is unsuited to the traditional newspaper style. Of course, there are exceptions to a reduction in story count, like the Express \& Star, where the culture of the family business is still high story count and talking to local people. In some cases there were also fewer stories in 1998 editions of the newspapers researched but this was due to the style of the newspaper, where in some newspaper groups there was an emphasis on bolder designs and fewer stories per page and also life-style content over news content. However, the decisions in 1998 for fewer stories were made for style reasons or a move away from news. The recent decisions around news production are based around the move to online first and staff cuts. Generally, the culture of bigger newspaper groups, which is web first, does not facilitate producing large quantities of local news stories for the printed edition or having the time to interview many local people. One question asked was whether it was important to have a high story count? There are varying opinions on this and whether it impacted on keeping sales high. What we know is that with the audience moving online, the rapid increase in the price of local newspapers and giving readers fewer stories, this has not helped to maintain the business. While this paints a gloomy picture for print, it is interesting to note that despite this decline, a recent American study has shown that local newspapers still continue to produce more content than any other media outlet (Napoli and Mahone, 2019). Also, it is worth noting that Reach Plc, the largest commercial, national and regional publisher in the UK still reports that print makes more in revenue than online (Reach Plc, 2019). The figures show that the company revenue was $£ 702 \mathrm{~m}$ of which print $£ 591 \mathrm{~m}$ was print revenue and $£ 107 \mathrm{~m}$ online (Tobbit, 2020). While the print figure is down year-on-year and the online figure up, it highlights that print is still a major contributor to the finances of a media company. This provides a glimmer of hope, but it also has a downside, if 
these newspapers continue to decline, who will provide local news and who will be talking to local people to the extent and scale produced by local newspapers before 2018 ?

\section{References}

Archant (2019). About us: our history. Archant.

Audit Bureau of Circulations - ABC (2019). Regional publications report - ABC. ABC. Retrieved from: https://www.abc.org.uk/report/regional. [Accessed 15 July 2019]

BBC News (2018). Daily Mirror owner changes name to Reach. BBC News.

BBC News (2020). Scotsman owner JPI media sold to national world for $£ 10.2 \mathrm{~m}$. BBC News.

Berry, J. D. (2004). Contemporary newspaper design: shaping the news in the digital age: typography \& image on modern newsprint. Mark Batty Publisher.

Cairncross, F. (2019). The Cairncross review: a sustainable future for journalism. Retrieved from: https://www.gov.uk/government/publications/the-cairncross-reviewa-sustainable-future-for-journalism. [Accessed 18 February 2019]

Dawson, C. (2002). Practical research methods: a user-friendly guide to mastering research. Oxford, U.K.: How To Books.

Deans, J. (2006). Northcliffe's cost-cutting target doubles. The Guardian.

Franklin, B., Murphy, D. (1998). Making the local news: local journalism in context. Psychology Press.

Frost, C. (2012). Designing for newspapers and magazines. Routledge.

Harcup, T. (2015). Journalism: principles and practice. SAGE Publications.

Harte, D. (2017). An investigation into hyperlocal journalism in the UK and how it creates value for citizens. $\mathrm{PhD}$ Thesis. Cardiff, U.K.: Cardiff University.

Hill, J. (2016). The British newspaper industry. London, UK: Palgrave Macmillan.

Hutton, A. (2018). The death of the local newspaper? BBC News.

Independent Press Standards Organisation - IPSO (2018). Editors' Code of Practice. IPSO.

Jenkins, J., Kleis Nielsen, R. (2018). The digital transition of local news. Retrieved from: https://www.digitalnewsreport.org/publications/2018/digital-transition-local-news/. [Accessed 13 March 2019]

Lambourne, H. (2014). Trinity Mirror writes down value of regional titles. HoldtheFront Page.

Linford, P. (2014). New chapter as Express \& Star switches to overnight. HoldtheFront Page.

Linford, P. (2018). JPI Media takes control of Johnston Press. HoldtheFrontPage.

Lipman, J. (2019). Google and Facebook have robbed journalism of its revenue streams. USA Today.

Mayhew, F. (2019a). Cairncross review: key facts and findings you might have missed. Press Gazette.

Mayhew, F. (2019b). UK local newspaper closures: net loss of 245 titles since 2005. Press Gazette.

Mayhew, F. (2017a). Regional ABCs online: London Evening Standard overtakes MEN to become most-visited regional news website. Press Gazette.

Mayhew, F. (2017b). Subbing hub move sees 78 Trinity Mirror regional newspaper journalists face redundancy. Press Gazette.

Napoli, P., Mahone, J., (2019). Local newspapers are suffering, but they're still (by far) the most significant journalism producers in their communities. Nieman Lab. Retrieved 
from: https://www.niemanlab.org/2019/09/local-newspapers-are-suffering-but-they re-still-by-far-the-most-significant-journalism-producers-in-their-communities/.

[Accessed 17 February 2020]

Nel, F. (2010). Laid off: what do UK Journalist do next? University of Central Lancashire, Lancashire, UK: journalism.co.uk.

Neuman, L. (2007). Basics of social research: qualitative and quantitative approaches. $2^{\text {nd }}$ Edition. Pearson.

Nilsson, P. (2019). Google to invest millions in UK news group. Financial Times.

Office for National Statistics (2016). Mid-year population estimates for major towns and cities. U.K.: Office for National Statistics.

Pape, S, Featherstone, S. (2005). Newspaper journalism: a practical introduction. SAGE Publications.

Perch, K. (2017). How the rise of online ads has prompted a 70 per cent cut in journalist numbers at big UK regional dailies. Press Gazette.

Ponsford, D. (2010). New Johnston Press subbing hub could see 20 jobs go in North West. Press Gazette.

Ponsford, D. (2020). Monty's back: JPI Media sold to David Montgomery's National World Plc for $£ 10.2 \mathrm{~m}$. Press Gazette.

Press Gazette (2013). DMGT completes sale of Northcliffe regional newspapers to Local World. Press Gazette.

Press Gazette (2014). 25 jobs set to be lost across Newsquest's Oxfordshire and Wiltshire division as part of subbing hub move. Press Gazette.

Reach Plc (2019). Financial report 2019. Retrieved from: https://www.reachplc.com/ home. [Accessed 29 May 2019]

Reeves, I. (2015). The newspapers handbook. $5^{\text {th }}$ Edition. Routledge.

Reid, A. (2014). How “newsroom 3.1" will change Trinity Mirror's local titles. Retrieved from: https://www.journalism.co.uk/news/how-newsroom-3-1-will-change-trinitymirror-s-local-titles/s2/a556221/. [Accessed 20 June 2017]

Sharman, D. (2017). Up to 40 jobs to go in Trinity Mirror shared content push. Holdthe FrontPage.

Spark, D., Harris, G. (1997). Practical newspaper reporting. CRC Press.

Spark, D., Harris, G. (2010). Practical newspaper reporting. SAGE Publications Inc.

Spark, D., Harris, G. (2016). Practical newspaper reporting. SAGE Publications Inc.

Sweney, M. (2016). Trinity Mirror confirms £220m Local World deal. The Guardian.

Tobbit, C. (2020). Reach to "accelerate" digital revenue with reader registrations as profits climb. Press Gazette.

Tracy, S. J. (2019). Qualitative research methods: collecting evidence, crafting analysis, communicating impact. Wiley.

Waterson, J. (2018). Facebook gives $£ 4.5 m$ to fund 80 local newspaper jobs in UK. The Guardian.

Waterson, J. (2020). Read all about it? How local papers' decline is starving communities of news. The Guardian.

Wright, M. (2019). 'Where have all the stories and voices gone in local newspapers? The effect falling advertising revenues and the rise of the web have had on English regional newspapers.' Interview by Richard Bowyer, May, 2019. 


\section{Appendix A}

\section{Questions Sent to Media Experts as Part of Research}

Question 1: From your experience, do you think there was an emphasis on story count in the last 30 years and, if so, was this detrimental to newspapers i.e., not enough to interest readers?

Question 2: Does the number of local stories in a regional newspapers matter? If so, why?

Question 3: I found there are fewer local stories in some newspapers now than there used to be, what is your view on this?

Question 4: Do you think there are fewer local stories in some local newspaper due to the reduction in staff, the emphasis changing to online first, or that the trend is towards fewer stories or other reasons? Explain fully;

Question 5: From my study, fewer local people are quoted in regional newspaper local stories, does it matter? 